\title{
Influence of winter weather changes on road pavement condition in Lithuania
}

\author{
Andrius Ružinskas, Henrikas Sivilevičius \\ Department of Transport Technological Equipment, Faculty of Transport Engineering, Plytiness st. 27, LT-10105, Vilnius, Lithuania
}

\begin{abstract}
Lithuania belongs to a special climatic zone, where winter usually lasts six months (from November till March). The air temperature is below zero for $3-4$ months. Moreover, thaws are frequent when temperature ranges about zero. There is ice formation on the road, freezing rain and fog possibilities in these conditions. Trying to forecast these phenomenon, in 1999 there was developed Road Weather Information System (RWIS) in the country. There were established 102 meteorological stations on the roads in 14 years period and this number increases every year. These stations can fix the temperature of air, road surface and dew point, the speed of wind, road condition and visibility. These data helps to evaluate traffic conditions in the roads and also helps to establish all three levels of road maintenance in winter. However, trying to optimize the fleet of winter road maintenance, it's necessary to investigate weather changes influence on road pavement condition using RWIS data. These data analysis could help to estimate road condition in winter and would help to forecast road maintenance in the future. This article describes tendencies of weather changes and values of parameters in winter over the years which can be usefull improving road maintenance system in winter.
\end{abstract}

Keywords: RWIS; winter weather; winter road maintenance.

\section{Introduction}

Winter highway operation and maintenance in the northern periphery is a challenge, a broad and complex area. Understanding about this area and its effect on winter traffic performance is far from complete.

In countries with severe winters (such like Lithuania), winter road safety is a source of concern for transportation officials. Driving conditions in winter can deteriorate and vary dramatically due to snowfall and ice formation, causing significant reduction in pavement friction and increasing risk of accidents [1].

The main climatic factors of the Lithuanian Republic (air temperature, depth of frozen ground, the wind, the sun radiation, precipitation) have great influence on the design, construction, and maintenance conditions of roads and streets $[2]$.

In most European countries road weather information systems (RWIS) have been established. The aim of these systems is to reduce the road maintenance costs in winter, to ensure good traffic safety, to inform drivers about poor traffic conditions [3].

The analysis results revealed that the enhanced accuracy and increased use of weather information could reduce winter maintenance costs. A benefit-cost analysis showed that weather information is a promising way to improve winter maintenance and reduced agency costs [4].

Appropriate use of weather data, collected from weather stations contribute to more effective winter road maintenance, but even if the weather stations are normally placed on roads where risk of icy roads is greatest, there are indirect factors which influence the planned maintenance of these tools which subsequently cause delay of winter road maintenance [5].

\section{Climatic conditions of winter in Lithuania}

Lithuania belongs to a specific climatic zone and climate is described as medium cold with snowy winter. The main climatic conditions are: amplitude and speed of temperature variation, maximum and minimum temperature, precipitation, wind

Corresponding author: Andrius Ružinskas. E-mail address: andrius.ruzinskas@vgtu.lt

http://dx.doi.org/10.3846/enviro.2014.167

(C) 2014 The Authors. Published by VGTU Press. This is an open-access article distributed under the terms of the Creative Commons Attribution License, which permits unrestricted use, distribution, and reproduction in any medium, provided the original author and source are credited. 
direction and speed, thickness of snow cover, depth of frozen ground. In winter Lithuania faces frequent thaws, the daily temperature varies around zero and there is a high probability of freezing rain, glazed frost and fog [6].

The dates when the first snow falls are close to the average dates when air temperature falls below zero. The earliest dates of the first snow in the east and the north of Lithuania are on approximately the 15th November, and the latest on the Pajurys lowland on the 25th November. However, permanent snow layer forms much later (after 3-4 weeks) due to frequent thaws. A permanent snow layer is a layer which stays for not less than one month with not longer than three-day breaks. The dates of permanent snow layer formation vary each year depending on the type of weather and atmospheric circulation [2]. In summary, the first snow cover forms from the middle of November and remains until middle of March. The permanent snow cover reaches $5 \mathrm{~cm}$ (western part of Lithuania) and 20-25 cm (northern part of Lithuania) and the coldest winter month is January.

The average number of days with glazed frost is 10-15 days per year (in differenct years up to 50 days) (December April period). The average duration of glazed frost is 12 hours (in some cases - up to $48 \mathrm{~h}$ ). 10-25 days per year with snowstorms and the average duration of one snowstorm reaches 5-7 hours, and the maximum $-30-40 \mathrm{~h}$. There are $60-80$ temperature changes from negative to positive and vice versa every year [7].

Mean temperature map for winter season is presented at Fig 1. The Map was made using data of 1981-2010 years [8].

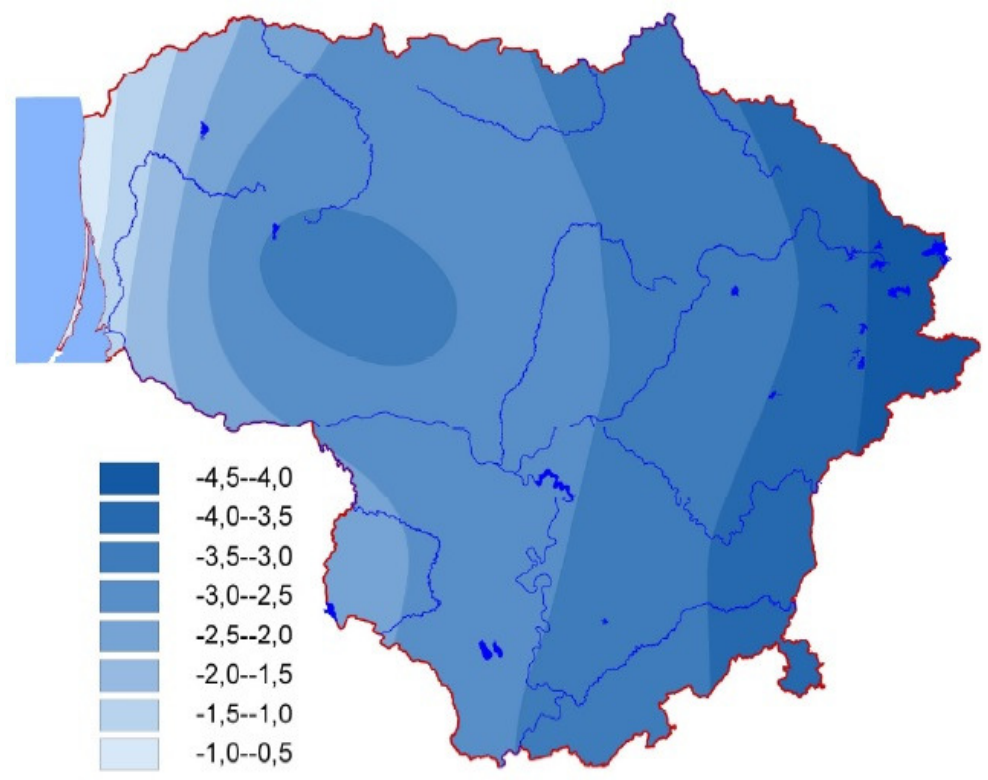

Fig. 1. Distribution of mean temperature in Lithuania by 1981-2010 years in winter (December-February) [8]

Highest temperature is in the east of country and lowest - in the west (at the seashore). Air temperature is one of the most important climate indicators. Fluctuations of air temperature are determined by geographical position, incoming solar radiation, global atmospheric air circulation, terrain conformation, distance from the sea and land cover characteristics. In 1981-2010 annual average temperature was $6,9^{\circ} \mathrm{C}$. The coldest month was January with $-3,2{ }^{\circ} \mathrm{C}$.

\section{Winter traffic conditions}

The roads of Lithuania up to 6 months per year are used in winter conditions. Condition of roads in winter shall be such as to allow vehicles to drive safely at a permissible speed throughout the whole cold period.

In winter traffic conditions are more complicated, since road pavement is covered with ice film; snow causes troubles with traffic conditions, snowdrifts reduce visibility, dark period of the day becomes longer. Snow makes a serious obstacle to traffic. A negative impact of snow on traffic conditions depends on its amount, on the intensity of snow or snowstorm and its repeated frequency, air temperature, speed and direction of wind and traffic volume. When it's snowing or the pavement being icy, the number of accidents increases, especially when rapid icing takes place or during freezing rain. The most dangerous for road traffic is freezing ice, covering road pavement with a thin, up to $1 \mathrm{~mm}$ thick, layer of ice [7].

If the maximum temperature is positive and the minimum - negative, a transition of air temperature across $0{ }^{\circ} \mathrm{C}$ takes place [9]. Temperature transition across $0{ }^{\circ} \mathrm{C}$ makes negative effect on road pavement condition and it is very important to know how many times this transition takes place. When there is water on the road, it could freeze and cause extremely dangerous driving conditions and could also increase probability of accidents.

When we are talking about winter traffic conditions, it's necesarry to mention friction coefficient between road and tire which especially depends on pavement condition (dry, wet, covered with snow or ice), design and condition of tyres and the driving speed. Friction coefficient can be defined by Eqn. (1). 


$$
\mu=\frac{N}{F}
$$

In which, $N$ is tire friction force and $F$ is a normal force. Some values of this coefficient are presented at table 1.

Table 1. Coefficient of friction on snow and ice [10]

\begin{tabular}{ll}
\hline Road surface & Coefficient of friction \\
\hline Battered snow & $0.24-0.37$ \\
\hline Non-battered snow & $0.15-0.42$ \\
\hline Snow and ice & $0.12-0.39$ \\
\hline Smooth ice & $0.054-0.19$ \\
\hline
\end{tabular}

Friction coefficient especially has huge influence on braking distance. When coefficient decreases the braking distance increases.

Vehicles driven on the snow covered road may encounter much more difficulties in keeping the maneuverability, owing to various unexpected situations such as idle rolling of tire, going off the driving lane and loss of braking, when compared to the well-paved road condition. The loss of maneuverability is mostly caused by excessive lack of friction and the high flexibility of snow. Tire contact with road surface is becoming very important in such a situation. When tire is driven on the snow-covered road, the undisturbed low-density snow is to be compacted, except for only a little amount of snow which is adhered to the tire tread. Snow at the tire leading edge is pulled into the tire contact patch, and then those are compressed mostly by the vehicle weight and the additional containment between the adjacent tread blocks. The snow compaction which makes the snow density higher and speeds up the icing is a dominant feature making the snow road distinct from other road conditions [11].

The snow compaction magnitude could be estimated by the snow sinkage $z$ which can be analytically calculated using the Bekker's pressure-sinkage Eqn. (2).

$$
z=h\left(1-\frac{\rho_{0}}{\rho_{f}}\right)=\left(\frac{p}{k}\right)^{\frac{1}{n}}
$$

where: $h$ is the thickness of undisturbed snow, $\rho_{0}$ and $\rho_{f}$ the initial and the final snow densities, $p$ the pressure, and $k$ and $n$ $(n>0)$ the snow constants, respectively.

Among all abnormal road conditions, it is widely known that the sno-covered road is characterized by the complexities in both the material properties and the tire behaviour. The material properties of snow, such as the density, friction coefficient and yield stress, show the strong dependence on the state of icing which is in turn affected by the snow compaction and the ambient temperature.

\section{Road Weather Information System (RWIS) in Lithuania}

Trying to optimize winter road maintenance in 1999 Lithuania started using road weather information system. The aim of the system is to collect and store data on extreme changes of weather conditions in the certain locations of the roads of national significance of Lithuania mostly affected by the climate. Information about road weather conditions is obtained by using automatic RWIS stations with the equipped sensors collecting information about different parameters of weather conditions. The whole information from these stations by using certain communication measures is transmitted to Traffic Information Centres where it is processed and disseminated to the users. The internet sites, developed for this special purpose, give information about weather and traffic conditions on roads. Automatic measurement stations are the main RWIS element, because they provide all required information. They are set at the main and regional roads all over the territory of Lithuania. These measurement stations are set in the specially selected places (close to water, in the shades, on bridges, etc.) where the unfavourable climatic factors occur firstly. For the selection of places for the stations special temperature diagrams are used [6].

Currently, there are 102 meteorological stations in 2014 [12]. 


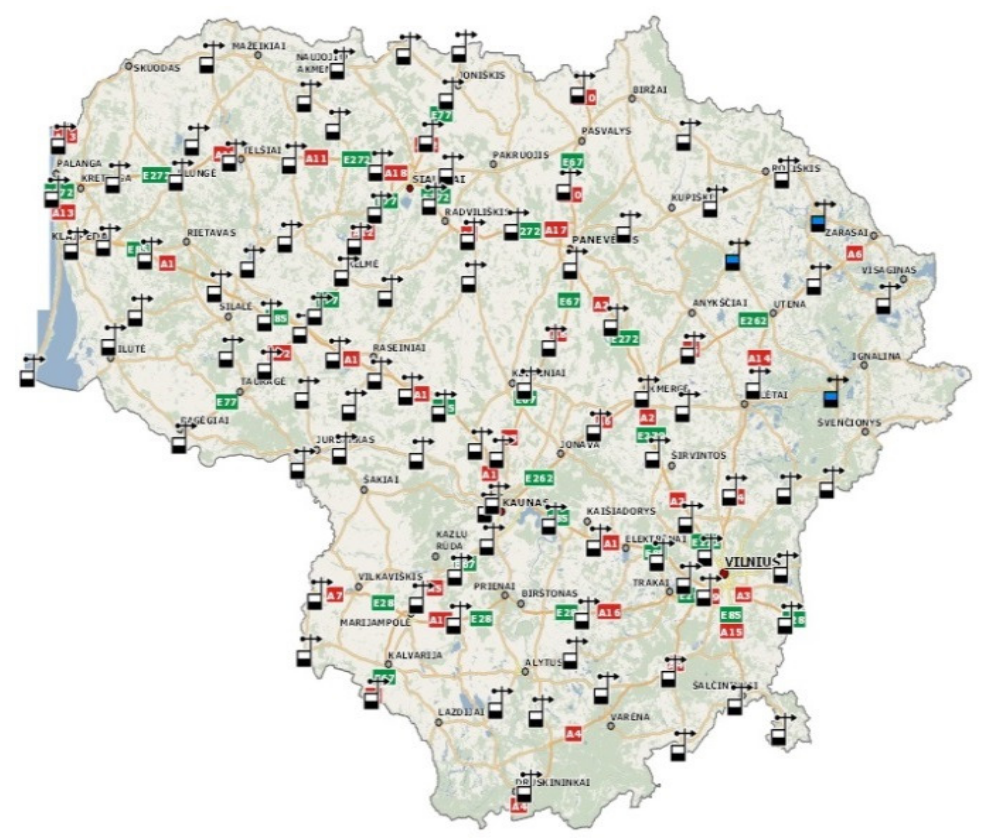

Fig. 2. Distribution of RWIS stations [12]

Fig. 2 schematically represents the dense distribution of stationary RWIS stations in Lithuania. The biggest number of stations are on A1 highway, because it is one of the important roads in whole country and it connects the biggest three cities of Lithuania.

RWIS stations are able to measure air temperature, humidity, the temperature of dew point, the amount and type of precipitation, the temperature of pavement surface, the temperature of pavement structure at the depth of 7, 20, 50, 80, 110 and $130 \mathrm{~cm}$, wind direction and speed, visibility (mist) also the potential/state of freezing and to present it according to the date, time and station. These all data are submitted in the 15 minutes range.

Some road/transport administrations and agencies around the world after using RWIS for several years experienced that

- the system has had a large cost benefit because the action can be applied before the occurrence of serious traffic accident and disasters.

- the system has been stable enough because of the high percentage of availability to measurement data.

- the system gives the ability to be proactive, which means that contractors can be warned before weather changes.

- the system gives the ability to automatic output data to variable speed signs which has the added benefit that drivers/motorists accept variable speed signs more readily than regular speed signs.

- the meteorogical offices can get input for their predictions.

The use of RWIS as an important assistive technology can also provide decision support to road administrations, road agencies and contractors. It can also contribute to weather forecasts that are more accurate [5].

\section{RWIS data analysis in winter}

For data analysis was chosen Pabrade station in the eastern of country and was analyzing data of 2003 year. This station was chosen because of its geographical position - it is in the east side of country, where usually air temperature (and also surface temperature) is higher than, for example, in the west of country because of the sea influence on this area. In Fig 3. surface and air temperatures and also air humidity changes in November at year 2003 are presented. We can see that it is a typical month of November with a few days of negative temperature. In many cases air temperature was higher than surface temperature.

A half of days of November was snowing and 4 days was raining, when 3 of them surface temperature was turning over $0{ }^{\circ} \mathrm{C}$, so driving conditions were extremely dangerous on these days. Means of temperatures and humidity of November March period are presented at Table 2. We can see that the mean of surface temperature is $0,5^{\circ} \mathrm{C}$ higher than air temperature in the month of November. 


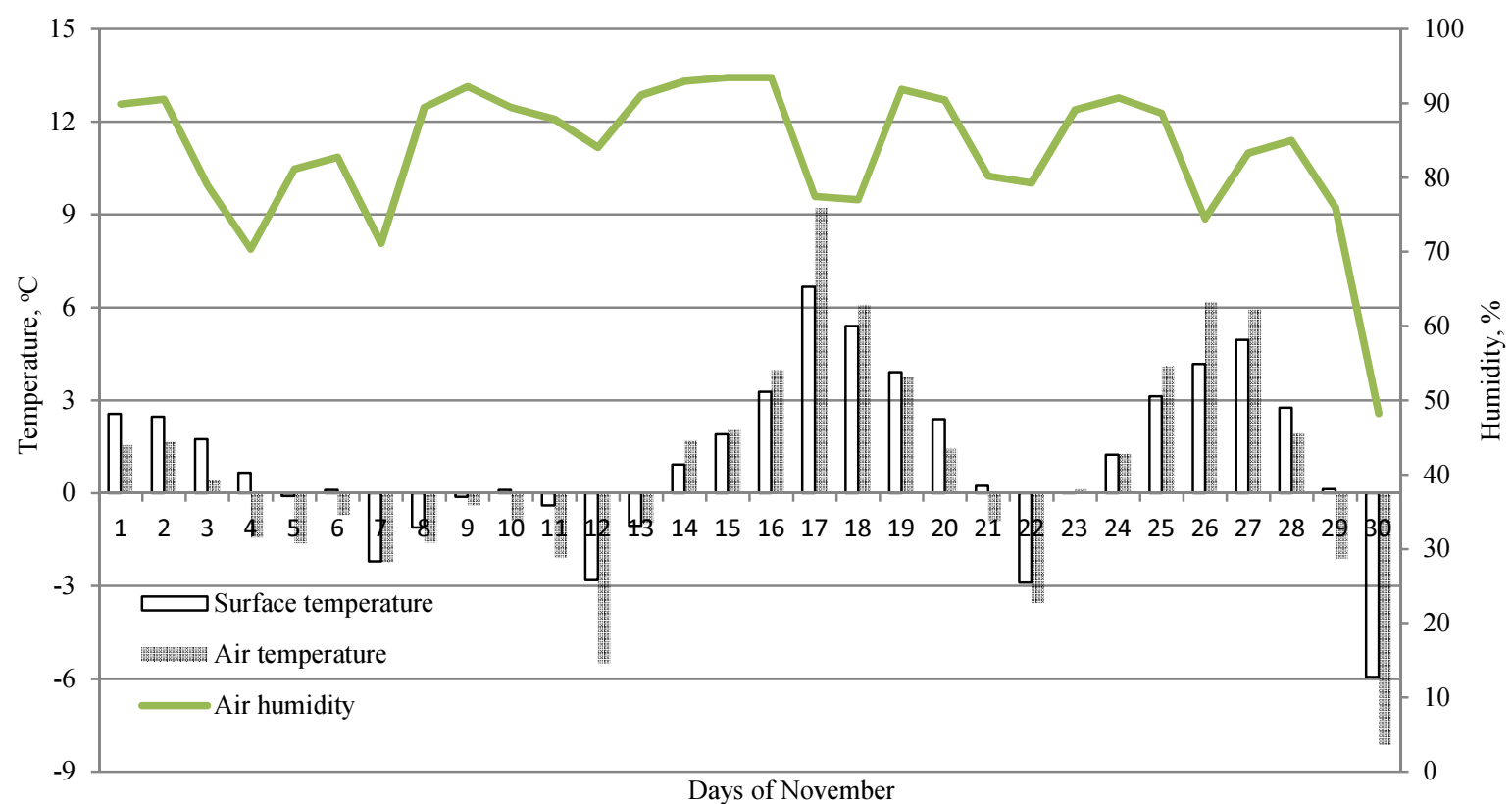

Fig. 3. Change of surface, air temperatures and air humidity in November at 2003

Table 2. Means and standard deviations values of air, surface temperatures and air humidity in November - March period

\begin{tabular}{|c|c|c|c|c|c|c|}
\hline Months & $\begin{array}{c}\text { Mean of } \\
\text { surfaceemperature } \\
\overline{T_{S}}\end{array}$ & Mean of air & $\begin{array}{l}\text { Mean of air } \\
\text { humidity } \bar{W}\end{array}$ & $\begin{array}{l}\text { Standard deviation } \\
\text { of surface } \\
\text { temperature } S_{T s}\end{array}$ & $\begin{array}{c}\text { Standard } \\
\text { deviation of air } \\
\text { temperature } S_{T a} .\end{array}$ & $\begin{array}{c}\text { Standard } \\
\text { deviation of air } \\
\text { humidity } S_{W}\end{array}$ \\
\hline November & 1,1 & 0,6 & 83,7 & 2,7 & 3,6 & 9,6 \\
\hline December & $-8,8$ & $-9,9$ & 79,9 & 4,1 & 5,0 & 9,9 \\
\hline January & $-6,5$ & $-6,4$ & 83,0 & 7,1 & 9,0 & 5,1 \\
\hline February & $-5,3$ & $-6,2$ & 82,6 & 3,8 & 4,8 & 5,9 \\
\hline March & 0,5 & $-0,8$ & 68,1 & 3,6 & 3,7 & 11,8 \\
\hline
\end{tabular}

From Table 2 we can see that lowest temperature was on December and highest on November. The month of December was extremely cold in this year and it shows that temperature changes are not the same in the years. The winter period was rather cold comparing with the values in Fig. 1, but temperature changes tendencies are the same - coldest months are December, January and February and warmest - November and March of the period, but in these months are the maximum number of times, when surface temperature changes over $0^{\circ}$. These numbers are presented in Fig. 4.

On the November there was 25 times when surface temperature was changing over $0{ }^{\circ} \mathrm{C}$ and on the March was even 38 times, but on December there was no time of this phenomenon. There was 43 days when this phenomenon occurs in the period and maximum was 4 cycles during a day. So in conclusion, the biggest number of temperature changes over $0^{\circ} \mathrm{C}$ is when cold period starts and when it ends so drivers must be especially careful on these months. In Fig. 4 is presented equation which allows to predict how many times will temperature change over $0{ }^{\circ} \mathrm{C}$ on the November - March period. This equation is approximately and if we want to get more accurate it is necessary to analyze more RWIS data but tendencies of distribution would be the same or similar to this research. 


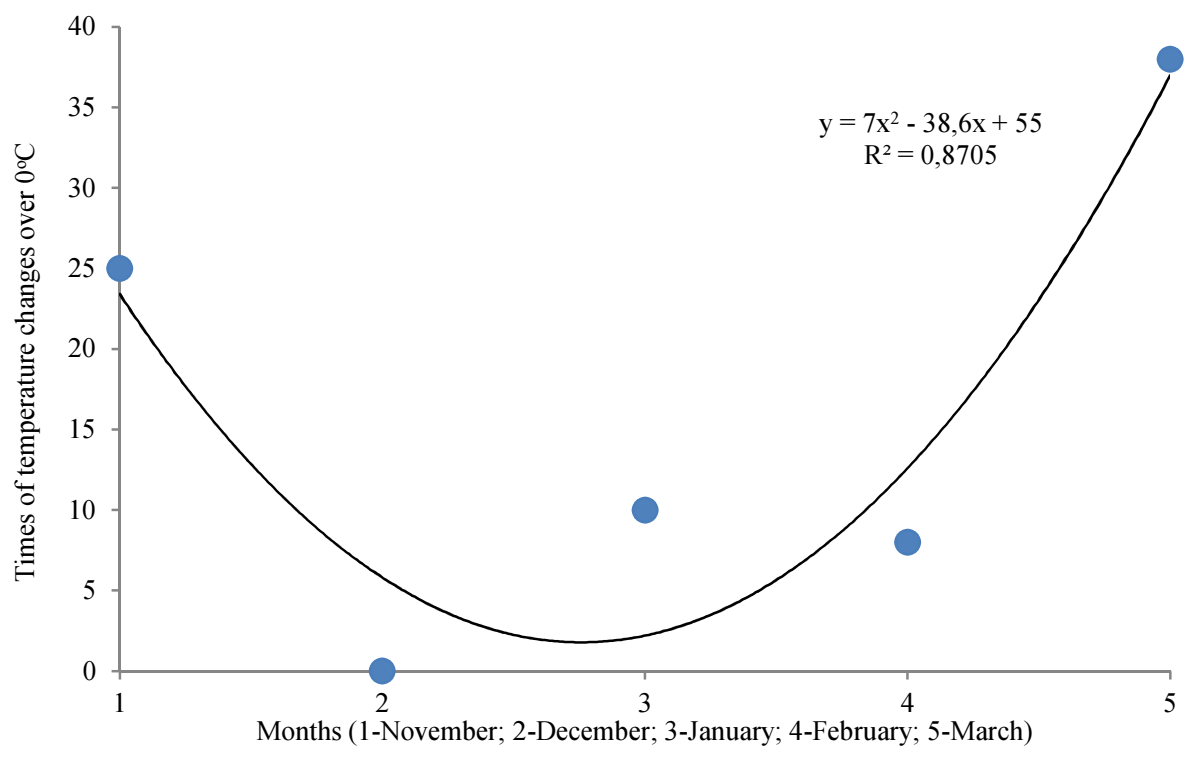

Fig 4. Times of temperature changes over $0{ }^{\circ} \mathrm{C}$ in November - March period

\section{Conclusions}

1. Winter climate of Lithuanian is quite complicated. It causes a lot of problem for drivers and for agencies of winter road maintenance. Freezing rain, ice and snow has negative influence on road pavement and these phenomenons must be eliminated as soon as possible, because increases road accident probability.

2. Solving the road maintenance problems in winter period, RWIS can be a good assistive tool. RWIS system is quite developed in Lithuania, there are over 100 stations whose measuring main parameters of winter weather (air and surface temperatures, air humidity, precipitation). The number of stations is increasing in every year.

3. RWIS data can be useful for predicting cycles of surface temperature changes over $0{ }^{\circ} \mathrm{C}$ (from negative to positive and vice versa). These cycles are very important for road users and road maintenance agencies because if there is water on the road, it could freeze and driving conditions would be complex and quite dangerous. The data analysis showed that biggest number of these cycles are on November and March, otherwise when cold period starts and ends. Also analysis showed that in some months there could be no cycles.

\section{References}

[1] Usman, T.; Fu, L.; Moreno, F. L. 2010. Quantifying safety benefit of winter road maintenance: accident frequency modeling, Accident Analysis and Prevention 42(2010): 1878-1887. http://dx.doi.org/10.1016/j.aap.2010.05.008

[2] Laurinavičius, A.; Čygas, D. 2003. Thermal conditions of road pavements and their influence on motor traffic, Transport 18(1): 23-31.

[3] Laurinavičius, A.; Čygas, D.; Čiuprinskas, K.; Juknevičiūtè, L. 2007. Data analysis and evaluation of road weather information system integrated in Lithuania, The Baltic Bridge of Road and Bridge Engineering 2(1): 5-11.

[4] Ye, Zh.; Shi, X.; Strong, K, Ch.; Greenfield, H. T. 2009. Evaluation of effects of weather information on winter maintenance costs, Journal of the Transportation Research Board 2107: 104-110. http://dx.doi.org/10.3141/2107-11

[5] Abdi, A.; Lind, H.; Birgisson, B. 2012. Use of road information system (RWIS) as assistive tool for effective winter road maintenance - technical and contractual interactions, International Journal of Engineerign and Technology 2(10): 2002-2012.

[6] Ratkevičius, T.; Laurinavičius, A.; Žilinskiené, J. L. 2013. Possibilities for the use of RWIS data in a building sector, Procedia Engineering 57: 938944. http://dx.doi.org/10.1016/j.proeng.2013.04.119

[7] Žilionienè, D.; Laurinavičius, A. 2007. Deicing experience in Lithuania, The Baltic Journal of Road and Bridge Engineering 2(2): 73-79.

[8] Vidutinès klimatinių rodiklių reikšmès Lietuvoje 1981-2010. Lietuvos hidrometeorologijos tarnyba prie Aplikos ministerijos [Lithuanian Hydrmometeorological Service under the Ministry of Evironment of the Republic of Lithuania], http://www.meteo.lt

[9] Leonovych, I.; Čygas, D. 2006. Road climatology: determination of calculated values of meterological characteristics, The Baltic Journal of Road and Bridge Engineering 1(4): 167-175.

[10] Sokolovskij, E. 2007. Automobile braking and traction characteristics on the different road surfaces, Transport 22(4): 275-278.

[11] Choi, H. J.; Cho, R. J.; Woo, S. J.; Kim, W. K. 2012. Numerical investigation of snow traction characteristics of 3-D patterned tire, Journal of Terramechanics 49 (2012): 81-93. http://dx. doi.org/10.1016/j.jterra.2012.01.003

[12] Eismo žemèlapis [Traffic map], 2013. Lietuvos automobilių kelių direkcija prie Susisiekimo ministerijos [Lithuanian Road Administration under the Ministry of Transport and Communications of the Republic of Lithuania], http://www.eismoinfo.lt 